\title{
Adherence to human lung microvascular endothelial cells (HMVEC-L) of Plasmodium vivax isolates from Colombia
}

\author{
Briegel De las salas ${ }^{1}$, Cesar Segura ${ }^{1}$, Adriana Pabón ${ }^{1,2}$, Stefanie CP Lopes ${ }^{3}$, Fabio TM Costa ${ }^{3}$ and Silvia Blair ${ }^{1 *}$
}

\begin{abstract}
Background: For years Plasmodium vivax has been considered the cause of benign malaria. Nevertheless, it has been observed that this parasite can produce a severe disease comparable to Plasmodium falciparum. It has been suggested that some physiopathogenic processes might be shared by these two species, such as cytoadherence. Recently, it has been demonstrated that $P$. vivax-infected erythrocytes ( $P$ v-iEs) have the capacity to adhere to endothelial cells, in which intercellular adhesion molecule-1 (ICAM-1) seems to be involved in this process.

Methods: Adherence capacity of 21 Colombian isolates, from patients with $P$. vivax mono-infection to a microvascular line of human lung endothelium (HMVEC-L) was assessed in static conditions and binding was evaluated at basal levels or in tumor necrosis factor (TNF) stimulated cells. The adherence specificity for the ICAM-1 receptor was determined through inhibition with an anti-CD54 monoclonal antibody.

Results: The majority of $P$. vivax isolates, 13 out of 21 (61.9\%), adhered to the HMVEC-L cells, but $P$. vivax adherence was at least seven times lower when compared to the four $P$. falciparum isolates. Moreover, HMVEC-L stimulation with TNF led to an increase of 1.6-fold in P. vivax cytoadhesion, similar to $P$. falciparum isolates (1.8-fold) at comparable conditions. Also, blockage of ICAM-1 receptor with specific antibodies showed a significant $50 \%$ adherence reduction.

Conclusions: Plasmodium vivax isolates found in Colombia are also capable of adhering specifically in vitro to lung endothelial cells, via ICAM-1 cell receptor, both at basal state and after cell stimulation with TNF. Collectively, these findings reinforce the concept of cytoadherence for $P$. vivax, but here, to a different endothelial cell line and using geographical distinct isolates, thus contributing to understanding $P$. vivax biology.
\end{abstract}

Keywords: Cytoadherence, Plasmodium vivax, Malaria, ICAM-1, Microvascular line of human lung endothelium, Colombia

\section{Background}

It has been estimated that Plasmodium vivax causes around 80-300 million cases per year, mainly in the Asian and Latin American regions [1]. For a long time P. vivax was considered the cause of benign malaria [1]. Nevertheless, it has been observed that this species can cause severe disease similar to Plasmodium falciparum and complications caused by $P$. vivax mono-infection have been described, such as cerebral malaria with

\footnotetext{
* Correspondence: silviablairt@gmail.com

'Grupo Malaria, Facultad de Medicina, Universidad de Antioquia UdeA, Calle 70 No. 52-21, Medellín, Colombia

Full list of author information is available at the end of the article
}

generalized seizures and epileptic status, severe anaemia, hepatic dysfunction and jaundice, acute lung lesion, acute respiratory distress syndrome (ARDS) and pulmonary oedema, shock, splenic rupture, acute renal failure and acute thrombocytopaenia with or without bleeding on different body sites [2-9]. Most recently, goes back to 2008 with the acquisition of $P$. vivax genomic sequence, it was found that around $80 \%$ of the genes are orthologous and mostly synthenic between the $P$. vivax and $P$. falciparum genomes [10-12]. Taken together this suggests that $P$. falciparum malaria pathogenic processes related to cytoadhesion may occur in P. vivax [13]. Furthermore, studies performed by Anstey

\section{Biomed Central}


et al. suggested that pulmonary lesions found in $P$. vivax malaria could be caused by sequestration of parasitic forms within this organ [14]. In this sense, Carvalho et al. reported that $P$. vivax has the ability to cytoadhere ex vivo to human lung endothelial cells (HLEC) and, to a lesser extent, to placenta cryosections. The adhesion found was similar in strength to that observed in P. falciparum, though ten times lower in number [13]. Accordingly, Chotivanich et al. demonstrated that $P$. vivax isolates from Thailand have the ability to adhere to chondroitin sulphate A (CSA) and to hyaluronic acid (HA) in placental sections [15-18]. Moreover, in 2012, Bernabeu et al. reported the participation of vir 14 protein in the adherence to ICAM-1 receptor on the Chinese hamster ovary $(\mathrm{CHO})$ cells transfected with human ICAM-1 (CHO-ICAM-1) cell line [18].

In Colombia, P. vivax continues to cause high impact on public health, with 83,255 (70.7\%) cases in 2010, from a total of 117,650 reported malaria cases. Severe P. vivax malaria cases have been described primarily in newborn, children and pregnant women $[9,19,20]$. Due to the emergence of complications caused by $P$. vivax infection and its cytoadherence capacity, the purpose of this study was to determine the adherence capacity of $P \nu$-iEs from Colombian patients, to human lung endothelial cells (HMVEC-L) mediated by ICAM-1 receptor in static conditions.

\section{Methods}

\section{Ethical considerations}

This study was approved by the Faculty of Medicine of the University of Antioquia's ethics committee records 012 18 June, 2009. All participants agreed to voluntarily donate their blood samples after signing an informed consent.

\section{Study area and subjects}

Up to $8.5 \mathrm{ml}$ of peripheral blood was collected from 21 $P$. vivax non-complicated malaria patients, diagnosed by the thick-smear method and confirmed by rapid diagnostic test (Bioline SD05FK80) and polymerase chain reaction (PCR) (to dismiss mixed infections at low levels). Seven patients, all from different places of the Department of Antioquia, were recruited at the University of Antioquia Malaria Group office in Medellin, and the remaining 14, at the Nuestra Señora del Carmen Hospital in El Bagre - Bajo Cauca- Department of Antioquia $\left(7^{\circ} 35^{\prime} 0^{\prime \prime} \mathrm{N}, 74^{\circ} 48^{\prime} 0^{\prime \prime} \mathrm{W}\right)$. To compare the $P$. vivax isolates adhesion, four $P$. falciparum isolates were adapted to in vitro culture [21].

\section{Isolation and concentration of Plasmodium vivax mature forms}

The methodology described by Carvalho et al. [13] was followed with few modifications. The initial patient parasitaemia was determined by counting the different parasitic forms in 200 leucocytes with an 8,000 leukocytes standard in order to obtain the amount of parasites per $\mu \mathrm{L}$. Samples were processed immediately after blood collection [22]. Plasma was removed by centrifugation at 2,500 rpm; for removal of WBC, blood was filtered with a Whatman CF11 cellulose column, the resultant pellet was washed three times using RPMI 1640 (Sigma) pH 7.2 medium, and resuspended to a $10 \%$ haematocrit. Later, the $P v$-iEs with mature forms (trophozoites, schizonts and gametocytes) were concentrated and separated from the young stages (rings) and non-infected erythrocytes. For this purpose, $5 \mathrm{~mL}$ of the $10 \%$ erythrocytes suspension were overlaid on $5 \mathrm{~mL}$ of $45 \%$ Percoll solution (Sigma P1644) and then the mixture was centrifuged at $2,500 \mathrm{rpm}$ for $20 \mathrm{~min}$ at $4^{\circ} \mathrm{C}$. The interphase containing mature forms was washed three times with RPMI-1640 $\mathrm{pH}$ 7.2. Mature stages were observed by thin smears (Figure 1). The estimated percentage of mature forms and the number of $P v$-iEs per $\mathrm{ml}$ was obtained using the Neubauer chamber count (0.0025 sq mm).

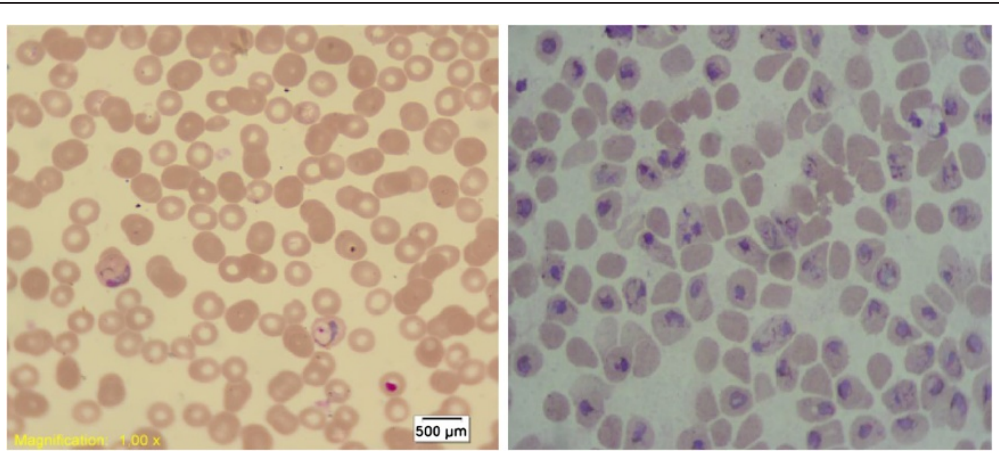

Figure 1 Percoll concentration, before and after enrichment 45\% Percoll gradient concentration of the mature stages of $P$. vivax. $1 \%$ Giemsa stain of trophozoites, schizonts and gametocytes. 100x objective. 


\section{Cultivation of Plasmodium falciparum blood forms} Plasmodium falciparum FCR3/Gambia strain (donated by National Institutes of Health- NIH, Laboratory of Malaria and Vector Research) were cultured following Trager and Jensen's method [21]. Mature stages concentration was carried out using 60\% Percoll [23].

\section{Isolation and concentration of Plasmodium falciparum mature forms harvested from infected patients}

The four field $P$. falciparum isolates were adapted to an in vitro culture and were maintained as described for FCR3 strain. The mature concentration stages were obtained with 1\% Gelatin flotation (Sigma G2625) [24]. The percentage of mature forms, and the number of $P$. falciparum-infected erythrocytes by $\mathrm{ml}$ were estimated using the Neubauer chamber count, as previously described [25].

Human lung endothelial cells (HMVEC-L) culture The HMVEC-L was maintained following the distributor's protocol (Lonza CC-2527), in endothelial basal medium -2 (EBM-2) (CC-3156) supplemented with endothelial growth medium (EGM-2) MV BulletKit from Lonza-Clonetics (CC-3202) at $37^{\circ} \mathrm{C}$ and $5 \% \mathrm{CO}_{2}$, until achieving a 70-90\% confluence. The cells were then treated with Trypsin-EDTA (Lonza) and seeded in Lab-Tek II 8 wells chambers (Brand-Products).

\section{Plasmodium vivax cytoadherence assay in static conditions}

Cytoadherence assays in static conditions were performed according to Carvalho et al. [13]. Briefly, HMVEC-L were seeded in Lab-Tek II chambers (Brand-Products), and $5 \times 10^{4}$ Percoll-enriched parasites per well were incubated in a total volume of $200 \mu \mathrm{L}$ cytoadhesion medium (RPMI1640, pH: 6.8) at $37^{\circ} \mathrm{C}$ for one hour in incubator agitation at $90 \mathrm{rpm}$ (IKA KS $4000 \mathrm{IC}$ Control). Non-adhered parasites and non-infected erythrocytes were removed by extensive washing in cytoadhesion medium. The adhered parasites were fixed using methanol for $2 \mathrm{~min}$, and stained with Giemsa 1\%. The number of parasites adhered were counted in a total of 200 HMVEC-L.

ICAM-1 (CD54) expression in HMVEC-L treated with TNF The ICAM-1 expression in HMVEC-L was induced by TNF treatment (10 ng/mL; Sigma-Aldrich) for $18-$
22 hours. The ICAM-1 expression levels evaluation was determined in a FACS Canto II flow cytometer (BD Biosciences) using a Mouse Anti-Human CD54 monoclonal (FITC-Conjugated, Millipore) for $30 \mathrm{~min}$, at $4^{\circ} \mathrm{C}$ in approximately 500,000 cells. The fluorescence intensity and percentage of positive cells for ICAM-1 was analysed in a minimum of 10,000 events acquired and analysed using the WinMDI 2.8 program. The adherence specificity to the ICAM-1 receptor was performed by previous incubation of HMVEC-L TNF stimulated cells with $10 \mu \mathrm{g} / \mathrm{ml}$ of anti-human CD54 monoclonal (clone 15,2 Serotec AbD MCA532) at room temperature for $30 \mathrm{~min}$ and then cytoadherence assay were performed as described.

\section{Statistical analysis}

The statistical significance of the performed comparisons was determined using the Mann-Whitney $U$ test. Calculations were performed using the IBM-SPSS Statistics 21 program, and the charts with the Prism Software (6.01 version; GraphPad Software). Differences were considered significant when a $\mathrm{p}<0.05$.

\section{Results}

A total of 21 P. vivax isolates confirmed through PCR were included. Average parasitaemia was 7,604.7 $\pm 6,963$ parasites $/ \mu \mathrm{L}$. These isolates came from different regions of Antioquia, mainly from Bajo-Cauca, and presented $>60 \%$ mature asexual stages predominance. The average age of the 21 patients was $28.4 \pm 14.1$ years and $15(71.4 \%)$ of them were males. The average parasitaemia of the adherent isolates was $9,461.5 \pm 4,280.6$ parasites/ $\mu \mathrm{L}$ (Table 1 ). Thirteen $P$. vivax isolates (61.9\%) presented adherence to HMVEC-L both at basal state and when cells were stimulated with TNF. The average basal state of $P v$-iEs per 200 HMVEC-L was $32.5 \pm 19.1$; and after TNF stimulation a 1.6 -fold increasing $(52.1 \pm 19.5, \mathrm{p}<0.001)$ in parasiteinfected erythrocytes was observed (Table 2) (Figure 2A and $B)$. No significant statistical differences $(p>0.05)$ between the parasitaemia averages from adherent and non-adherent parasites were noticed.

Adherence of four P. falciparum isolates at basal state was $161.8 \pm 196.2$ and with TNF stimulation adhesion reach to $368.7 \pm 429.1$ (1.8-fold) and the adherence observed in the P. falciparum strain (FCR3) was $201 \pm 61$ parasite infected erythrocytes and after TNF stimulation it was $465 \pm 498$ (Table 2) (Figure 2C).

Table 1 Percentage of cytoadherence of Plasmodium vivax isolates

\begin{tabular}{llllll}
\hline & & Frequency & Percentage & Average parasitaemia parasites/ $\boldsymbol{\mu L}(\mathrm{SD})$ & Significance $(\mathbf{9 5 \% )}$ \\
\hline P. vivax isolates & Adherent & 13 & 61.9 & $9,461.5(7766.1)$ & 0.122 \\
& Non-adherent & 8 & 38.1 & $4,587.5(4280.6)$ & \\
& Total & 21 & 100.0 & & \\
\hline
\end{tabular}

Total cytoadherence of $P$. vivax isolates, average parasitaemia and their standard deviations, significance value $95 \%$. 
Table 2 Cytoadherence of Plasmodium vivax and Plasmodium falciparum isolates in HMVEC-L basal and stimulated with TNF-a

\begin{tabular}{|c|c|c|c|}
\hline \multirow{3}{*}{$\begin{array}{l}\text { Isolate } \\
\text { P. vivax } \\
\text { (code) }\end{array}$} & \multirow{2}{*}{\multicolumn{2}{|c|}{ Adherence $^{1}$}} & \multirow{3}{*}{$\begin{array}{l}\text { Adherence (\% of inhibition) } \\
\text { Anti-CD54 }\end{array}$} \\
\hline & & & \\
\hline & Basal & $\begin{array}{l}\text { Stimulated } \\
\text { TNF- } a\end{array}$ & \\
\hline 0.012 & $19.0 \pm 1$ & $27.0 \pm 2$ & ND \\
\hline 0.013 & $19.5 \pm 2.5$ & $39.5 \pm 5.5$ & ND \\
\hline 0.014 & $10.5 \pm 1.5$ & $33.5 \pm 3.5$ & ND \\
\hline 0.015 & $4.0 \pm 1$ & $24.5 \pm 2.5$ & ND \\
\hline 0.017 & $42.0 \pm 4$ & $51.0 \pm 16$ & ND \\
\hline 0.018 & $28.0 \pm 3$ & $52.0 \pm 7$ & $31.5(39.4)$ \\
\hline 0.019 & $38.0 \pm 9$ & $58.5 \pm 6.5$ & 34 (41.9) \\
\hline 0.022 & $37.0 \pm 11$ & $81.5 \pm 2.5$ & $36.5(55.2)$ \\
\hline 0.024 & $53.0 \pm 6$ & $77.5 \pm 10.5$ & $33.5(56.8)$ \\
\hline 0.025 & $28.5 \pm 6.5$ & $67.5 \pm 3.5$ & $23.5(56.8)$ \\
\hline 0.026 & $55.5 \pm 7.5$ & $69.5 \pm 11.5$ & $27(61.2)$ \\
\hline 0.027 & $35.5 \pm 10.5$ & $47.0 \pm 8$ & $42(10.6)$ \\
\hline 0.028 & $22.0 \pm 4$ & $48.5 \pm 4.5$ & $22(54.6)$ \\
\hline \multicolumn{3}{|c|}{ P. falciparum } & \\
\hline 0.033 & $58.5 \pm 13.4$ & $113 \pm 16.9$ & \\
\hline 0.034 & $17 \pm 7.1$ & $53 \pm 8.5$ & \\
\hline 0.035 & $475 \pm 38.2$ & $1050 \pm 74.9$ & \\
\hline 0.036 & $97 \pm 8.5$ & $259 \pm 24$ & \\
\hline FCR3 & $201 \pm 49.8$ & $465 \pm 61$ & \\
\hline
\end{tabular}

P. vivax and $P$. falciparum isolates cytoadherence to microvascular line of human lung endothelium HMVEC-L, from the isolate code $0.018-0.028$ the percentage of adherence inhibition is described, compared to endothelial cells treated with TNF.

${ }^{1 .}$ Average \pm standard deviation of $P v$-iEs per 200 HMVEC-L.
The involvement of the ICAM-1 receptor (CD54) in parasite cytoadherence was determined in eight $P$. vivax isolates through cytoadherence inhibition assay using the monoclonal antibody anti-CD54 in TNF stimulated cells. A 50\% cytoadherence reduction was observed in the average of adhered $P v$-iEs/200 HMVEC-L, compared to cells without antibody anti-CD54, $62.7 \pm 19.5$ vs. $31.2 \pm$ 8.8 Pv-iEs (Figure 3).

\section{Discussion}

Cytoadherence of $P$. vivax isolates from Colombia was demonstrated using primary microvascular endothelial lung cells in static conditions as respiratory distress are one of the most frequently malaria vivax complication reported [26-29]. These assays revealed that the majority of $P$. vivax isolates, 13 out of 21 (61.9\%), adhered to the lung endothelial cells and stimulation with TNF lead to a significant increase of 1.6 -fold in $P$. vivax cytoadherence. Moreover, blockage of ICAM-1 receptor with specific antibodies showed a 50\% significant reduction in parasite binding, thus demonstrating a $P$. vivax ability to adhere to the ICAM-1 receptor. As expected, P. vivax adherence was at least seven times lower in comparison to $P$. falciparum isolates. This latter finding is consistent with a previous report using Brazilian isolates [13].

The involvement of TNF in malaria pathogenesis has already been demonstrated in experimental cerebral malaria model [30]. The TNF released by monocytes in response to the endothelium damage or in the presence of soluble factors derived from the parasite such as glycosyl-phosphatidylinositol (GP-I) and haemozoin, increases ICAM-1 levels expressed in endothelial cells, and therefore enhances leukocytes and platelets adhesion and parasite sequestration to the endothelium [30,31]. Moreover, inflammatory co-morbidities, including
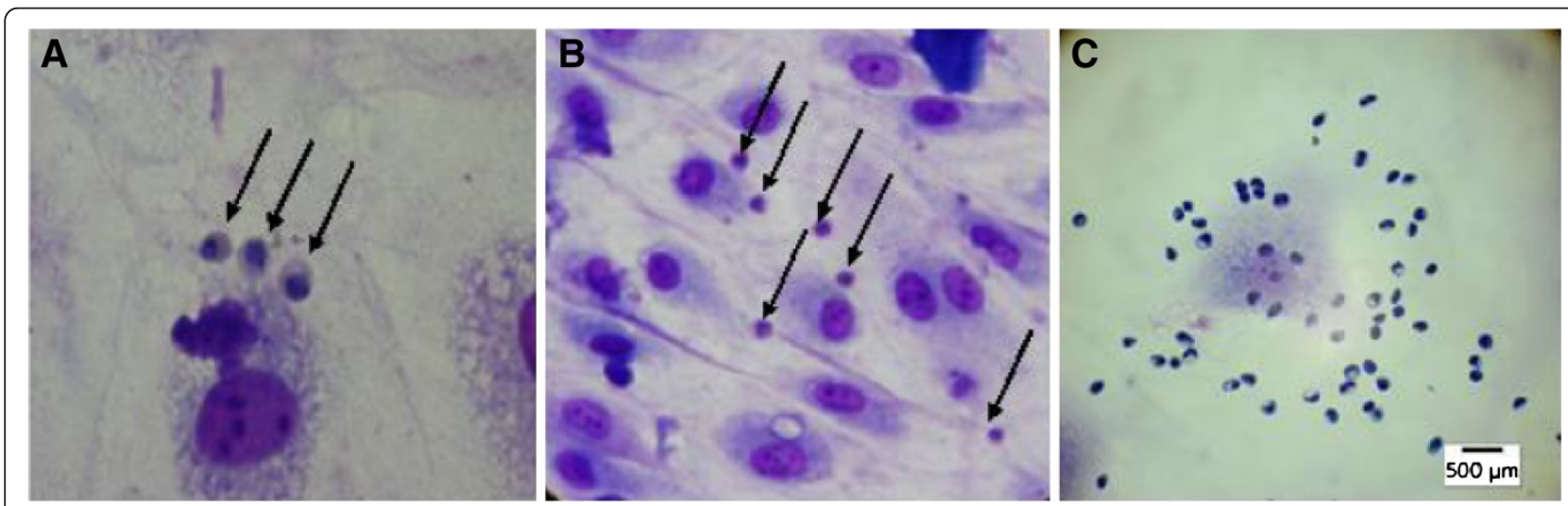

Figure 2 Cytoadherence of clinical isolates of Plasmodium sp. to human lung endothelial cells HMVEC-L A and B. Cytoadherence of PV-iEs to human lung endothelial cells HMVEC-L. 1\% Giemsa stain. C. Cytoadherence of Pf-iEs to human lung endothelial cells HMVEC-L. A 100X, B 40X and C 40x objective. 


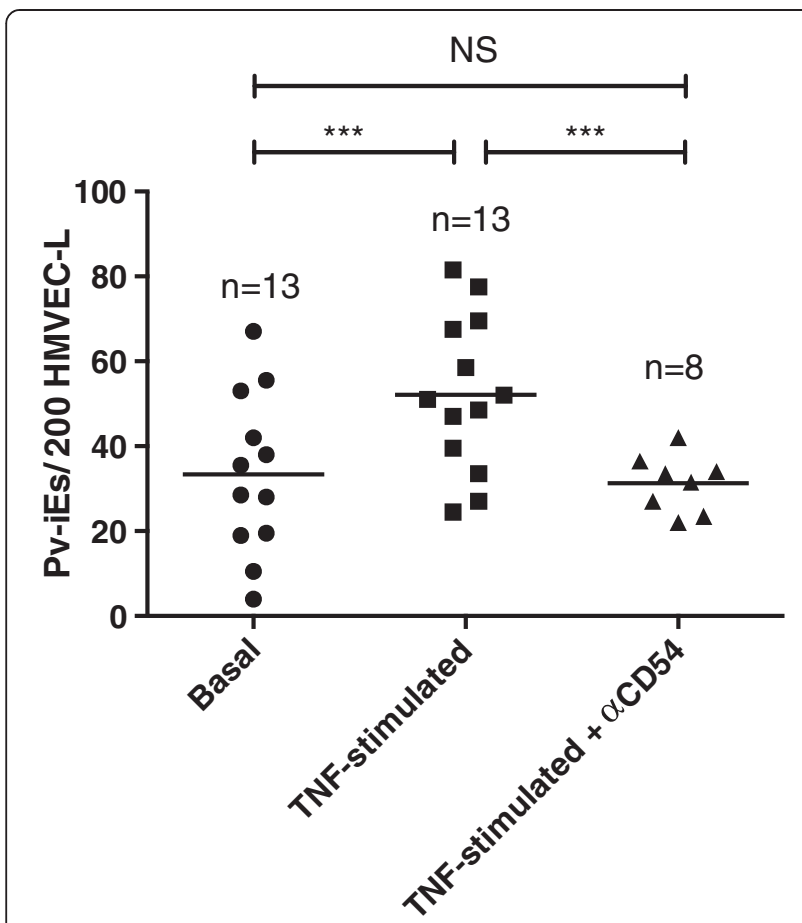

Figure 3 Average adherence of $P v$-iEs to the ICAM-1 endothelial receptor. $5^{*} 10^{4}$ parasites/well were added to HMVEC-L-TNF, HMVEC-L-TNF- antiCD54 mAb, or to the basal control HMVEC-L. The scatter plot shows adherence data is an average of the number of $P$ V-iEs/200HMVEC-L; Asterisks indicate statistical significance with respect to adhesion values, as follows: ${ }^{*} 0.05>p>0.01$; ${ }^{* *} 0.01>p>0.001 ;{ }^{* * *} p<0.001$

bacterial infections, seem to play a key role in $P$. vivax clinical complications [3]. Therefore, endothelial cells were treated with TNF prior to $P v$-iEs adhesion as demonstrated. These results suggest that in an ICAM-1 overexpression scenario due to high expression of TNF allowed $P$. vivax to improve its adhesion ability. In order to explore this hypothesis, the ICAM-1 receptor was blocked using anti-CD54 showing an average reduction of $50 \%$ in the cytoadherence in TNF stimulated cells; even in some of the isolates was below basal levels. This demonstrates its role in cytoadherence and suggests the participation of other endothelial receptors, such as hyaluronic acid (HA) and chondroitin sulphate A (CSA). Plasmodium vivax adherence to ICAM-1 receptor has already been suggest by Carvalho et al., who demonstrated a significantly higher $P v$-iEs adherence to CHO ICAM-1 transfected cells in comparison to mock $\mathrm{CHO}$. The findings by Bernabeu et al. indicate the involvement of VIR14 protein in ICAM-1 cytoadherence [18].

Collectively, this study reinforces the recent findings about $P$. vivax ability to cytoadhere to endothelial cells and highlights the importance of ICAM-1 endothelial receptors in this phenomenon.
Competing interests

All authors declare that they have no competing interests.

\section{Authors' contributions}

$\mathrm{BD}$ carried out laboratory work, analysed the data and helped to draft the manuscript. AP participated in the data analyses and helped to draft the manuscript. SB and CS conceived and coordinated the study. BD, AP, SCPL and FTMC design of the study and performed the statistical analysis. All authors read and approved the final manuscript.

\section{Acknowledgments}

The authors would like to thank the patients for their willingness during the samples collection, and the Nuestra Señora del Carmen Hospital staff in El Bagre - Department of Antioquia for lending us the malaria sample collecting equipment, and the clinical laboratory for letting us use their equipment. Ana María Vásquez Cardona, PhD Biology student, for her unconditional support in the experimental development of the investigation, and the Grupo Malaria. This work was supported by Colciencias (Grant 111549326146, RC-489-2009) and the Universidad de Antioquia, Colombia (CODI- Estrategia de Sostenibilidad 2013-2014). BD, AP, CS and SB were sponsored by Colciencias (Grant 111549326146, RC-489-2009) and the Universidad de Antioquia, Colombia (CODI- Estrategia de Sostenibilidad 20132014). FTMC is enrolled at the Programa Estratégico de Ciência, Tecnologia \& Inovação nas Fundações Estaduais de Saúde (PECTI/AM Saúde) from Fundação de Amparo à Pesquisa do Estado do Amazonas (FAPEAM, Amazonas - Brazil). SCPL was supported by a FAPESP fellowship and CNPq-Universal grant.

\section{Author details}

${ }^{1}$ Grupo Malaria, Facultad de Medicina, Universidad de Antioquia UdeA, Calle 70 No. 52-21, Medellín, Colombia. ${ }^{2}$ Programa de Biología, Facultad de Ciencias Básicas, Universidad del Atlántico, 080001, Barranquilla, Colombia. ${ }^{3}$ Departamento de Genética, Evolução e Bioagentes, Universidade Estadual de Campinas (UNICAMP), Campinas, SP, Brazil.

Received: 29 July 2013 Accepted: 24 September 2013

Published: 30 September 2013

\section{References}

1. Mueller I, Galinski MR, Baird JK, Carlton JM, Kochar DK, Alonso PL, del Portillo HA: Key gaps in the knowledge of Plasmodium vivax, a neglected human malaria parasite. Lancet Infect Dis 2009, 9:555-566.

2. Tjitra E, Anstey NM, Sugiarto P, Warikar N, Kenangalem E, Karyana M, Lampah DA, Price RN: Multidrug-resistant Plasmodium vivax associated with severe and fatal malaria: a prospective study in Papua, Indonesia. PLoS Med 2008, 5:e128.

3. Alexandre MA, Ferreira CO, Siqueira AM, Magalhaes BL, Mourao MP, Lacerda MV Alecrim M: Severe Plasmodium vivax malaria, Brazilian Amazon. Emerg Infect Dis 2010, 16:1611-1614.

4. Harish R, Gupta S: Plasmodium vivax malaria presenting with severe thrombocytopenia, cerebral complications and hydrocephalus. Indian J Pediatr 2009, 76:551-552.

5. Kute V, Goswami J, Vanikar A, Shah P, Gumber M, Patel H, Kanodia K, Trivedi $\mathrm{H}$ : Unusual presentation of Plasmodium vivax: a neglected human malaria parasite. Parasitol Res 2012, 110:2573-2576.

6. Zubairi* A, Fazal A, Raza A, Husain J, Beg A: Pulmonary complications of Plasmodium vivax malaria. Chest 2012, 142:194A.

7. George P, Alexander LM: A study on the clinical profile of complicated Plasmodium vivax mono-infections. Asian Pac J Trop Med 2010, 3:560-562.

8. Valecha N, Pinto RG, Turner GD, Kumar A, Rodrigues S, Dubhashi NG, Rodrigues E, Banaulikar SS, Singh R, Dash AP, Baird JK: Histopathology of fatal respiratory distress caused by Plasmodium vivax malaria. Am J Trop Med Hyg 2009, 81:758-762.

9. Arboleda M, Pérez MF, Fernández D, Usuga LY, Meza M: Perfil clínico y de laboratorio de los pacientes con malaria por Plasmodium vivax, hospitalizados en Apartadó, Colombia. Biomedica 2012, 32:58-67.

10. Tan LK, Yacoub S, Scott S, Bhagani S, Jacobs M: Acute lung injury and other serious complications of Plasmodium vivax malaria. Lancet Infect Dis 2008, 8:449-454.

11. Carlton JM, Adams JH, Silva JC, Bidwell SL, Lorenzi H, Caler E, Crabtree J, Angiuoli SV, Merino EF, Amedeo P, Cheng Q, Coulson RM, Crabb BS, Del Portillo HA, Essien K, Feldblyum TV, Gilson PR, Guo X, Kang'a S, Kooij TW, 
Korsinczky V, Meyer EV, Nene V, Paulsen I, Ralph V, Ren Q, Sargeant TJ, Salzberg SL, Stoeckert CJ, Sullivan SA, et al: Comparative genomics of the neglected human malaria parasite Plasmodium vivax. Nature 2008, 455:757-763.

12. Gupta P, Das A, Singh OP, Ghosh SK, Singh V: Assessing the genetic diversity of the vir genes in Indian Plasmodium vivax population. Acta Trop 2012, 124:133-139.

13. Carvalho BO, Lopes SCP, Nogueira PA, Orlandi PP, Bargieri DY, Blanco YC, Mamoni R, Leite JA, Rodrigues MM, Soares IS, Oliveira TR, Wunderlich G, Lacerda MVG, Del Portillo HA, Araújo MOG, Russell B, Suwanarusk R, Snounou G, Rénia L, Costa FTM: On the cytoadhesion of Plasmodium vivax-infected erythrocytes. J Infect Dis 2010, 202:638-647.

14. Anstey NM, Handojo T, Pain MC, Kenangalem E, Tjitra E, Price RN, Maguire GP: Lung injury in vivax malaria: pathophysiological evidence for pulmonary vascular sequestration and posttreatment alveolar-capillary inflammation. J Infect Dis 2007, 195:589-596.

15. Chotivanich K, Udomsangpetch R, Suwanarusk R, Pukrittayakamee $S$, Wilairatana P, Beeson JG, Day NP, White NJ: Plasmodium vivax adherence to placental glycosaminoglycans. PLoS One 2012, 7:e34509.

16. Oliveira T, Fernandez-Becerra C, Jimenez MC, Del Portillo H, Soares I: Evaluation of the acquired immune responses to Plasmodium vivax VIR variant antigens in individuals living in malaria-endemic areas of Brazil. Malar J 2006, 5:83.

17. Fernandez-Becerra C, Pein O, de Oliveira TR, Yamamoto MM, Cassola AC, Rocha C, Soares IS, de Bragança Pereira CA, del Portillo HA: Variant proteins of Plasmodium vivax are not clonally expressed in natural infections. Mol Microbiol 2005, 58:648-658.

18. Bernabeu M, Lopez FJ, Ferrer M, Martin-Jaular L, Razaname A, Corradin G, Maier AG, del Portillo HA, Fernandez-Becerra C: Functional analysis of Plasmodium vivax VIR proteins reveals different subcellular localizations and cytoadherence to the ICAM-1 endothelial receptor. Cell Microbiol 2012, 14:386-400.

19. Piñeros-Jiménez JG, Arboleda M, Jaramillo JC, Blair S: Reporte de cinco casos de malaria neonatal grave por Plasmodium vivax en Urabá, Colombia. Biomedica 2008, 28:471-479.

20. Carmona-Fonseca J, Maestre-B A: Incidencia de las malarias gestacional, congénita y placentaria en Urabá (Antioquia, Colombia), 2005-2007. Rev Colomb Obstet Ginecol 2009, 60:19-33.

21. Trager $W$, Jensen JB: Human malaria parasites in continuous culture. Science 1976, 193:673-675.

22. Pabón A, Álvarez G, Yánez J, Céspedes C, Rodríguez Y, Restrepo Á, Blair S: Evaluación de la prueba rápida inmunocromatográfica Binax NOW ${ }^{\circledast}$ ICT $\mathrm{Pf} / \mathrm{Pv}$ para el diagnóstico del paludismo en un área endémica de Colombia. Biomedica 2007, 27:225-235.

23. Fernandez V, Treutiger CJ, Nash GB, Wahlgren M: Multiple adhesive phenotypes linked to rosetting binding of erythrocytes in Plasmodium falciparum malaria. Infect Immun 1998, 66:2969-2975.

24. Goodyer ID, Johnson J, Eisenthal R, Hayes DJ: Purification of mature-stage Plasmodium falciparum by gelatine flotation. Ann Trop Med Parasitol 1994, 88:209-211.

25. Duraisingh MT, Roper C, Walliker D, Warhurst DC: Increased sensitivity to the antimalarials mefloquine and artemisinin is conferred by mutations in the pfmdr1 gene of Plasmodium falciparum. Mol Microbiol 2000, 36:955-961.

26. Lomar AV, Vidal JE, Lomar FP, Barbas CV, Matos GJ, Boulos M: Acute respiratory distress syndrome due to vivax malaria: case report and literature review. Braz J Infect Dis 2005, 9:425-430.

27. Kumar S, Melzer M, Dodds P, Watson J, Ord R: Plasmodium vivax malaria complicated by shock and ARDS. Scand J Infect Dis 2007, 39:255-256.

28. Tanios MA, Kogelman L, McGovern B, Hassoun PM: Acute respiratory distress syndrome complicating Plasmodium vivax malaria. Crit Care Med 2001, 29:665-667.
29. Martínez O: Síndrome de dificultad respiratoria aguda en malaria por Plasmodium vivax. Acta Med Colomb 1996, 21:146-150.

30. Engwerda C, Belnoue E, Gruner AC, Renia L: Experimental models of cerebral malaria. Curr Top Microbiol Immunol 2005, 297:103-143.

31. Coban C, Ishii KJ, Horii T, Akira S: Manipulation of host innate immune responses by the malaria parasite. Trends Parasitol 2007, 15:271-278.

doi:10.1186/1475-2875-12-347

Cite this article as: De las salas et al:: Adherence to human lung microvascular endothelial cells (HMVEC-L) of Plasmodium vivax isolates from Colombia. Malaria Journal 2013 12:347.

\section{Submit your next manuscript to BioMed Central and take full advantage of:}

- Convenient online submission

- Thorough peer review

- No space constraints or color figure charges

- Immediate publication on acceptance

- Inclusion in PubMed, CAS, Scopus and Google Scholar

- Research which is freely available for redistribution

Submit your manuscript at www.biomedcentral.com/submit
C) BioMed Central 